05

\title{
TRENDS AND PERSPECTIVES OF SUSTAINABLE POTATO PRODUCTION IN ALIGARH DISTRICT, INDIA
}

\author{
Nizamuddin Khan ${ }^{1}$, Anisur Rehman ${ }^{2}$, Mohd. Sadiq Salman ${ }^{3}$ and Kamal Asif ${ }^{4}$ \\ ${ }^{1}$ Professor, Department of Geography, A.M.U., Aligarh, India \\ ${ }^{2}$ Ex-Guest Faculty, Department of Geography, A.M.U., Aligarh, India \\ ${ }^{3}$ Guest Faculty, Department of Geography, J.M.I., New Delhi, India \\ ${ }^{4} \mathrm{Head}$, Department of Geography, D.P.S., Aligarh, India \\ Email: kasif2006bustan@gmail.com,mmsadiqsalman@gmail.com
}

\begin{abstract}
The rural population in India is largely engaged in vegetable cultivation apart from traditional agricultural practices. Vegetable cultivation has gained impetus since last decades due to increasing health awareness, population growth, urbanization and better marketing facilities. Earlier, small land holders used to grow vegetables but now with increasing demand and higher remunerations large land holders have also shifted towards vegetable cultivation. Potato is widely used due to its low cost, easy handling and transportation and its higher shelf life as compare to other vegetables. The present paper analyzes the dynamics of potato cultivation in Aligarh district, which is one the leading producing area of India. This paper tends to find out temporal change in the area under potato cultivation and substantial increase in the total production. There are promising benefits to the potato farmers and good prospects in future due increasing cold storage and agro-processing facilities. The present study also discusses the role various institutional, socio-economic, marketing and policy oriented factors constraining potato cultivation in the study area.
\end{abstract}

Key words: Potato Cultivation, Veg. Farming, Agricultural Marketing, Farmers' Sustainability

\section{Introduction}

India with diverse soil and climate comprising several agro-ecological regions provides ample opportunity to grow a variety of horticultural crops. These crops form a significant part of total agricultural produce in the country which covers fruits, vegetables, root and tuber crops, flowers, and ornamental, medicinal and aromatic plants, spices, condiments, plantation crops and mushrooms. Cultivation of these crops is labour intensive and generates lot of employment opportunities for the rural population. India, with more than 66 million tonnes of vegetables is the second largest producer vegetables in the world next only to Brazil and China (Economic Census 2005). Thus, cultivation of diversified crops plays a vital role in the prosperity of the nation and is directly linked with the health and happiness of the people (Asif, K. et al., 2016).

Potato is a starchy tuber of the plant Solanum tuberosum, native to the Andes in South America. It was introduced in Europe by the Spanish invaders and diffused to several countries. It is grown in more than 125 countries and consumed almost daily by more than a billion people. Hundreds of millions of people in developing countries depend on potatoes for their survival. Potato is also referred as the 'food of the poor'. In India also potato is reported to be very important during the times of food scarcity (Shakeel, et al., 2012). Once harvested, potatoes can be used for a variety of purposes: as a fresh vegetable for cooking at home, as raw material for processing into food products, food ingredients, starch and alcohol, as feed for animals, and as seed tubers for growing the next season's crop (FAO, 2009).

Potato cultivation is expanding strongly in the developing world, where the potato's ease of cultivation and nutritive content has made it a valuable food security and cash crop for millions of farmers. Developing countries are now the world's biggest producers and importers of potatoes and potato products. In India, potato was introduced by the Portuguese during $17^{\text {th }}$ 
Century AD. It was first cultivated in the mountains of the Western Ghats, Nilgiris and later on in the North India. At present potato is the most important and widely used vegetable in India. As a vegetable, potato is cultivated in almost all states of India. The major potato producing States are Uttar Pradesh, West Bengal, Bihar, Gujarat, Madhya Pradesh, Punjab, Haryana and Assam. Vegetable cultivation under market gardening is an important component of the value added cropping system of Indian agriculture. Earlier vegetables were cultivated as subsistence crops along with cereals, pulses and oilseeds and occupied a meagre share of total cropped area of the country. It is a caste oriented activity and mainly cultivated at small scale (Deshingkar P. et al. 2003). The cultivation of vegetable was traditionally confined to certain castes and still persists in larger parts of the country. Hence, this kind of cropping system could not get proper attention by the policy makers as well as by large farmers.

Table 01: State wise Production of Potato and its Share (in Percent)

\begin{tabular}{|c|c|c|}
\hline \multirow[t]{2}{*}{ State/UTs } & \multicolumn{2}{|c|}{$\begin{array}{c}\text { Five Year Average } \\
(2012-13 \text { to 2016-17) }\end{array}$} \\
\hline & Production & Percent Share \\
\hline Uttar Pradesh & 14502.63 & 31.96 \\
\hline West Bengal & 10425.58 & 22.97 \\
\hline Bihar & 6449.06 & 14.21 \\
\hline Gujarat & 3015.68 & 6.64 \\
\hline Madhya Pradesh & 2858.30 & 6.30 \\
\hline Punjab & 2278.43 & 5.02 \\
\hline Haryana & 769.17 & 1.69 \\
\hline Assam & 1039.31 & 2.29 \\
\hline Chhattisgarh & 625.87 & 1.38 \\
\hline Jharkhand & 653.61 & 1.44 \\
\hline Maharashtra & 335.97 & 0.74 \\
\hline Karnataka & 558.04 & 1.23 \\
\hline Uttarakhand & 403.04 & 0.89 \\
\hline Odisha & 260.13 & 0.57 \\
\hline Rajasthan & 166.93 & 0.37 \\
\hline Meghalaya & 184.75 & 0.41 \\
\hline Himachal Pradesh & 210.56 & 0.46 \\
\hline Tripura & 146.88 & 0.32 \\
\hline Jammu \& Kashmir & 127.96 & 0.28 \\
\hline Nagaland & 57.74 & 0.13 \\
\hline Tamil Nadu & 103.25 & 0.23 \\
\hline Sikkim & 51.18 & 0.11 \\
\hline Andhra Pradesh & 74.51 & 0.16 \\
\hline Kerala & 7.71 & 0.02 \\
\hline Mizoram & 2.01 & 0.00 \\
\hline Telangana & 61.82 & 0.14 \\
\hline Arunachal Pradesh & 1.13 & 0.00 \\
\hline Others & 14.70 & 0.03 \\
\hline TOTAL & 45383.50 & 100.00 \\
\hline
\end{tabular}

Source: State Departments of Horticulture \& Agriculture

The Table 01 shows the state wise average share of potato production in India for the last five years. It is revealed that the whole Indo-Gangetic Plain is important for potato cultivation and the largest production is reported from Uttar Pradesh (31.96 percent) followed by West Bengal (22.97 percent ) and Bihar (14.21 percent). Among the Himalayan states a good performance has shown by the states of Uttarakhand ( 0.89 percent) and Himachal Pradesh (0.46 percent). In the North Eastern region, Assam (2.29 percent) followed by Meghalaya (0.41 percent) is the leading producer. Whereas, in the peninsular region Karnataka (1.23 percent), followed by Maharashtra ( 0.74 percent) and Tamil Nadu ( 0.23 percent), is the leading. However, the other states of peninsular region are lacking in potato cultivation. 
The present paper aims to understand the dynamics of potato cultivation in the Northern Plains of Ganga River with the help of a case study. Aligarh district in the doab (land between two rivers) region of western Uttar Pradesh has been selected as study area (Asif, K., 2014). This region is a well-known potato belt of India. Here potato cultivation has a boon due to the availability of sandy loam soils and suitable climatic condition during winter season (rabi season between October and March). In the present study researchers analyze the area and production of potato in various development blocks of Aligarh District to understand the future prospects of potato cultivation. The paper intends to highlights the problems of the farmers, particularly related to the storage, marketing and processing.

\section{About the Study Area}

The Aligarh district is situated in the semi-arid eco-system of the Western Uttar Pradesh. Geographically, Aligarh district is located in the fertile tract of rivers the Ganga and the Yamuna between $27^{\circ} 29^{\prime}$ to $28^{\circ} 11^{\prime} \mathrm{N}$ latitudes and $77^{\circ} 29^{\prime}$ to $78^{\circ} 38^{\prime} \mathrm{E}$ longitudes. There are 5 Tehsils/subdivisions and 12 development blocks in the district. The total geographical area is 3650 sq.km, with a population of $36,73,849$ (1,951,996 males and 1,721,893 females) (Census, 2011). The district has a population density of 1,007 persons per sq. $\mathrm{km}$. The population growth rate over the decade 2001-2011 was 22.78 percent. Aligarh has a sex ratio of 876 females for every 1000 males, and a literacy rate of 69.61 percent. About 65 percent of the workforce is engaged in agricultural activities. There are 1210 villages and 13 townships, 96 rural markets and 4 regulated markets in the study area for transaction of vegetables in the study area. The district is further sub- divided into 12 developmental blocks (Figure 01). Vegetable cultivation is an age-old farming system in Aligarh district.

Figure 01: Study Area: Aligarh District (2019)

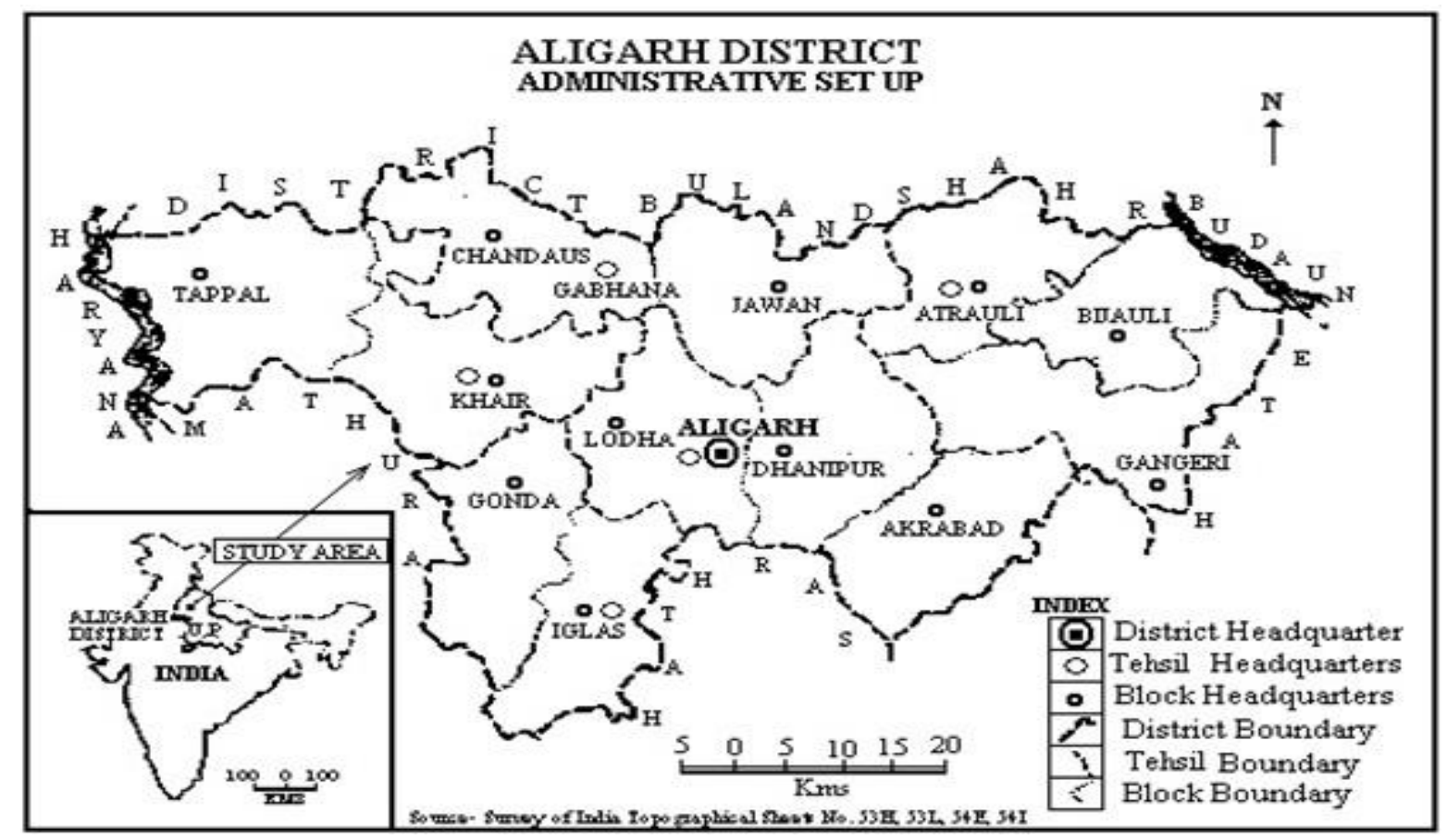

The region experiences sub-tropical monsoon type of climate characterized by distinct seasonal rhythm. Summers start around April and continue till June with a mean maximum temperature of $40^{\circ} \mathrm{C}$, occasionally shooting up to $46^{\circ} \mathrm{C}$, while during winters it goes as low as $4^{\circ} \mathrm{C}$. The average annual rainfall is about $55 \mathrm{~cm}$ that follow the summer season and usually starts up to the end of the June (Asif, K., 2014). Aligarh district is an extensive plain comprising alluvial soils, which are characterized by their depth and gray-brown colour. Their texture varies from sandy, sandy loam to clay loam. Jowar, bajra, maize, cotton, paddy, arhar and moong are major crops during kharif, while wheat, mustard, green peas and potato are commonly grown in 
rabi season. Cotton and sugarcane (with small area) are major cash crops of the district. Vegetable cultivation is largely confined to small and marginal farmers who are located mainly in the peri-urban areas (Khan N. et al., 2012).

\section{Database and Methodology}

The present study is based on secondary sources of data obtained from statistical bulletin of Aligarh district. The latest data available for block wise area under potato cultivation was used for the present work. Thus, block wise data from 2001- 2016 was used in the present study. The data regarding area, production and yield of potato in the district has been processed and computed. The study carries out with simple statistical techniques to analyze and interpret data. The dataset obtained was analyzed to understand the prospects of potato cultivation and the changes in trends of area, production and productivity of potato in the study area.

\section{Analysis and Discussion}

The Table 02 shows the block wise distribution of area under potato cultivation since 2001. It reveals that the area under potato cultivation during 2001 was only 5,425 hectares which increased to 24,987 hectares in 2016 (Figure 02). Thus a growth of 19,562 hectares (360.59 percent) took place over last 15 years. The steep rise in the area under potato cultivation is largely due to increasing population, better marketing and transportation facilities, rising consciousness of health benefits from vegetable intake, increasing urban demand for processed food items and agro-processing industries. The block wise variation is also observed in the study area. It varied from 89 hectares in Atrauli to 7,176 hectares in Iglas, during last 15 years. Thus, it was observed that all the blocks have small area under potato cultivation while only few blocks gave large area under its cultivation.

Table 02: Block wise Distribution of Area under Potato Cultivation (2001-2016)

\begin{tabular}{|c|c|c|c|c|c|c|c|c|c|c|c|c|c|c|c|c|}
\hline \multirow{2}{*}{ Block } & \multicolumn{16}{|c|}{ Block wise Area Under Potato Cultivation (in hectares) } \\
\hline & 2001 & 2002 & 2003 & 2004 & 2005 & 2006 & 2007 & 2008 & 2009 & 2010 & 2011 & 2012 & 2013 & 2014 & 2015 & 2016 \\
\hline Bijauli & 244 & 156 & 216 & 187 & 230 & 248 & 256 & 335 & 422 & 330 & 353 & 363 & 331 & 321 & 350 & 393 \\
\hline Jawan & 165 & 217 & 221 & 123 & 188 & 189 & 194 & 254 & 268 & 338 & 370 & 380 & 341 & 342 & 409 & 405 \\
\hline Akrabad & 130 & 139 & 177 & 204 & 201 & 231 & 301 & 394 & 481 & 404 & 452 & 464 & 424 & 465 & 480 & 505 \\
\hline Gangiri & 258 & 283 & 378 & 358 & 391 & 392 & 446 & 584 & 671 & 495 & 476 & 489 & 446 & 419 & 411 & 552 \\
\hline Atrauli & 540 & 463 & 564 & 590 & 533 & 522 & 650 & 891 & 938 & 498 & 565 & 580 & 529 & 581 & 590 & 629 \\
\hline Tappal & 28 & 17 & 215 & 261 & 200 & 134 & 133 & 174 & 184 & 798 & 773 & 794 & 724 & 744 & 821 & 861 \\
\hline Chandaus & 174 & 151 & 220 & 89 & 230 & 342 & 289 & 378 & 399 & 660 & 926 & 951 & 868 & 902 & 1105 & 1032 \\
\hline Dhanipur & 371 & 245 & 351 & 333 & 306 & 305 & 235 & 308 & 325 & 603 & 969 & 995 & 908 & 900 & 980 & 1080 \\
\hline Khair & 39 & 637 & 702 & 823 & 772 & 508 & 505 & 661 & 698 & 1859 & 1883 & 1934 & 1765 & 1783 & 1788 & 2079 \\
\hline Lodha & 261 & 276 & 398 & 339 & 496 & 817 & 989 & 1294 & 1365 & 1736 & 1978 & 2032 & 1854 & 1924 & 2099 & 2206 \\
\hline Gonda & 861 & 845 & 1215 & 1313 & 1487 & 2575 & 3268 & 4277 & 4513 & 4410 & 5127 & 5266 & 4805 & 5201 & 5429 & 5715 \\
\hline Iglas & 2354 & 2318 & 377 & 3763 & 3411 & 5437 & 6184 & 8094 & 8242 & 7501 & 8549 & 8781 & 8012 & 9210 & 9620 & 9530 \\
\hline Total & 5425 & 5747 & 5034 & 8383 & 8445 & 11700 & 13450 & 17644 & 18506 & 19632 & 22421 & 23029 & 21007 & 22792 & 24082 & 24987 \\
\hline
\end{tabular}

Source: Statistical Booklets (2001-2016)

Figure 02: Total Area under Potato Cultivation in Aligarh District (2001-2016)

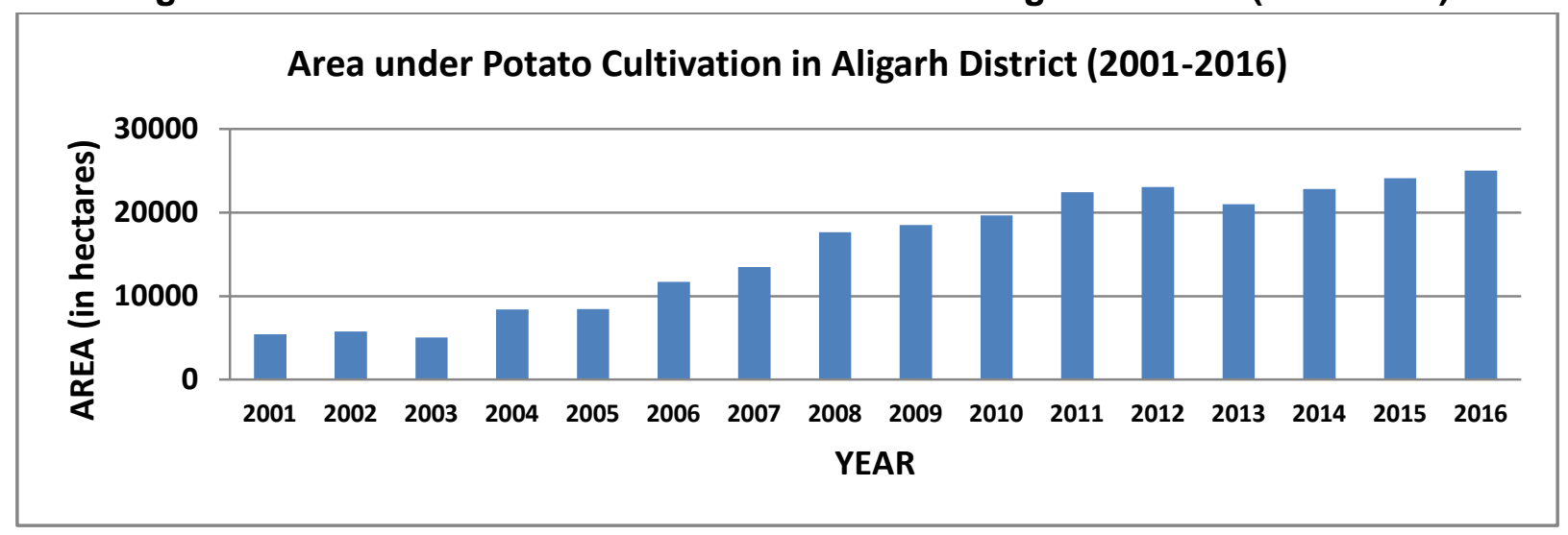


The change in area under potato cultivation was observed in all the blocks in the district. Although there is an overall growth of 19,562 hectare in the total area under potato cultivation since last 15 years there is a large variation at the block level. All the blocks have shown a positive change although with high level of variations(Table 03). The maximum change was observed in Iglas block (7,176 hectares) followed by Gonda (4,854 hectares) and Khair block $(2,040$ hectares $)$. It was observed that largest change has taken place in Iglas followed by Gonda blocks which had the largest and second largest area under potato during 2001 also. In 2001 Atrauli had third position in area under potato cultivation but it has shown minimum growth of only 89 hectares. Further Khair, Lodha, Tappal and Chandaus blocks have shown an exceptional growth during the same period. These blocks are adjoining the Iglas and Gonda block and people have gradually devoted their land to potato cultivation. Further, the development of marketing facilities over the last decade due to development of efficient transport networks, better connectivity to adjoining areas and increase in the number of cold storage facilities in these blocks has helped in growth of potato cultivation in the western blocks of the district.

Table 03: Block wise Growth of Area under Potato Farming (2001-2016)

\begin{tabular}{|l|c|c|c|c|}
\hline \multirow{2}{*}{ Name of Block } & & & \multicolumn{2}{|c|}{ Change (2001-2016) } \\
\cline { 4 - 5 } & $\mathbf{2 0 0 1}$ & $\mathbf{2 0 1 6}$ & Hectares & Percent \\
\hline Iglas & 2354 & 9530 & 7176 & 304.84 \\
\hline Gonda & 861 & 5715 & 4854 & 563.76 \\
\hline Khair & 39 & 2079 & 2040 & 5230.77 \\
\hline Lodha & 261 & 2206 & 1945 & 745.21 \\
\hline Chandaus & 174 & 1032 & 858 & 493.10 \\
\hline Tappal & 28 & 861 & 833 & 2975.00 \\
\hline Dhanipur & 371 & 1080 & 709 & 191.11 \\
\hline Akrabad & 130 & 505 & 375 & 288.46 \\
\hline Gangiri & 258 & 552 & 294 & 113.95 \\
\hline Jawan & 165 & 405 & 240 & 145.45 \\
\hline Bijauli & 244 & 393 & 149 & 61.07 \\
\hline Atrauli & 540 & 629 & 89 & 16.48 \\
\hline Total District & $\mathbf{5 4 2 5}$ & $\mathbf{2 6 3 7 4}$ & $\mathbf{2 0 9 4 9}$ & $\mathbf{3 8 6 . 1 6}$ \\
\hline
\end{tabular}

Source: Statistical Booklets (2001-2016)

Table 04: Area, Yield and Total Production of Potato in Aligarh District (2001-2016)

\begin{tabular}{|c|c|c|c|}
\hline Year & $\begin{array}{c}\text { Total Area } \\
\text { (hectares) }\end{array}$ & $\begin{array}{c}\text { Yield } \\
\text { (quintals/hectares) }\end{array}$ & $\begin{array}{c}\text { Production } \\
\text { (quintals) }\end{array}$ \\
\hline 2001 & 5425 & 263.49 & 1429433.25 \\
\hline 2002 & 5747 & 261.46 & 1502610.62 \\
\hline 2003 & 5034 & 245.22 & 1234437.48 \\
\hline 2004 & 8383 & 225.25 & 1888270.75 \\
\hline 2005 & 8445 & 283.80 & 2396691.00 \\
\hline 2006 & 11700 & 232.62 & 2721654.00 \\
\hline 2007 & 13450 & 234.03 & 3147703.50 \\
\hline 2008 & 17644 & 213.39 & 3765053.16 \\
\hline 2009 & 18506 & 220.52 & 4080943.12 \\
\hline 2010 & 19632 & 271.47 & 5329499.04 \\
\hline 2011 & 22421 & 245.92 & 5513772.32 \\
\hline 2012 & 23029 & 230.92 & 5317856.68 \\
\hline 2013 & 21007 & 276.18 & 5801713.26 \\
\hline 2014 & 22792 & 249.26 & 5681133.92 \\
\hline 2015 & 24082 & 259.8 & 6256503.60 \\
\hline 2016 & 24987 & 267.05 & 6672778.35 \\
\hline
\end{tabular}

Source: Statistical Booklets (2001-2016) 
The Table 04 shows the area, yield and production of potato from 2001 to 2016. It was observed that the area under potato has increased considerable but yield has not increased significantly. The yield of potato in 2001 was 263.49 quintals/hectare which became 267.05 quintals/hectare in 2016. Thus, we can easily conclude that heavy increase in the production of potato is associated with the increase in area rather than yield which has remained almost the same since 2001. However, there may have overall fluctuation in the yield due to yearly variations in the inputs and climatic elements. This shows that, the traditional practice is still followed and new methods and techniques to increase the yield of the crop is not available or adopted by the farmers in the study area.

Table 05: Change in Total Production of Potato in Aligarh District (2001-2016)

\begin{tabular}{|c|c|c|c|}
\hline \multirow{2}{*}{ Year } & $\begin{array}{c}\text { Production } \\
\text { (quintals) }\end{array}$ & \multicolumn{2}{|c|}{ Change in Production } \\
\cline { 3 - 4 } & 1429433.25 & - & (in Percent) \\
\hline 2001 & 1502610.62 & 73177.37 & - \\
\hline 2002 & 1234437.48 & -268173.00 & 5.12 \\
\hline 2003 & 1888270.75 & 653833.30 & -17.84 \\
\hline 2004 & 2396691.00 & 508420.30 & 52.96 \\
\hline 2005 & 2721654.00 & 324963.00 & 26.93 \\
\hline 2006 & 3147703.50 & 426049.50 & 13.56 \\
\hline 2007 & 3765053.16 & 617349.70 & 15.65 \\
\hline 2008 & 4080943.12 & 315890.00 & 19.61 \\
\hline 2009 & 5329499.04 & 1248556.00 & 8.39 \\
\hline 2010 & 5513772.32 & 184273.30 & 30.59 \\
\hline 2011 & 5317856.68 & -195916.00 & 3.46 \\
\hline 2012 & 5801713.26 & 483856.60 & -3.55 \\
\hline 2013 & 5681133.92 & -120579.34 & 9.09 \\
\hline 2014 & 6256503.60 & 575369.68 & -2.08 \\
\hline 2015 & 6672778.35 & 416274.75 & 10.13 \\
\hline 2016 & & & 6.65 \\
\hline
\end{tabular}

Source: Computed by the Researchers based on Table 04

Figure 03: Total Production of Potato in Aligarh District (2001-2016)

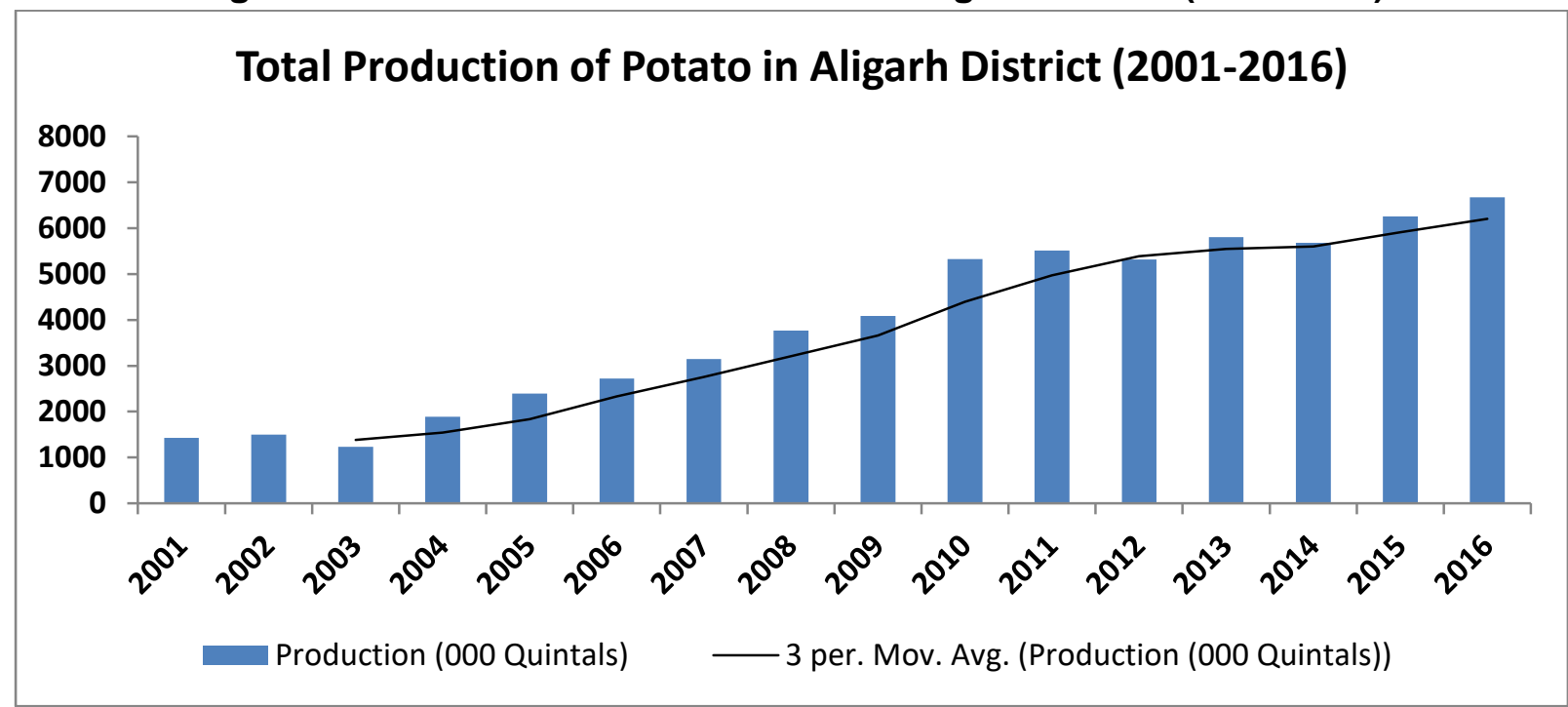

The total production of potato in the study area has increased from 14,29,433.25 quintals in 2001 to $66,72,778.35$ quintals in 2016. Thus, an increase of 52,43,345.10 quintals has been recorded during 15 years. This accounted for an average annual increase of 
$3,49,556.34$ quintals. The production has increased regularly since the area under cultivation has increased steadily over the last 15 years (Figures 02 and 03). There is a regular increase in production over the last 13 years apart from 2003 and 2012 which showed a decline in potato production. The minimum increase in volume of potato production was $73,177.37$ quintals found in 2002 whereas maximum increase was observed to be $12,48,556$ quintals in 2010 followed by $6,53,833.3$ quintals in 2004. Further, in terms of increase in percentage the minimum was 3.46 percent in 2011 whereas the maximum increase was observed as 52.96 percent in 2004 (Table 05).

\section{Figure 04 Potato Farming and Harvesting in the Iglas Block of Aligarh District}

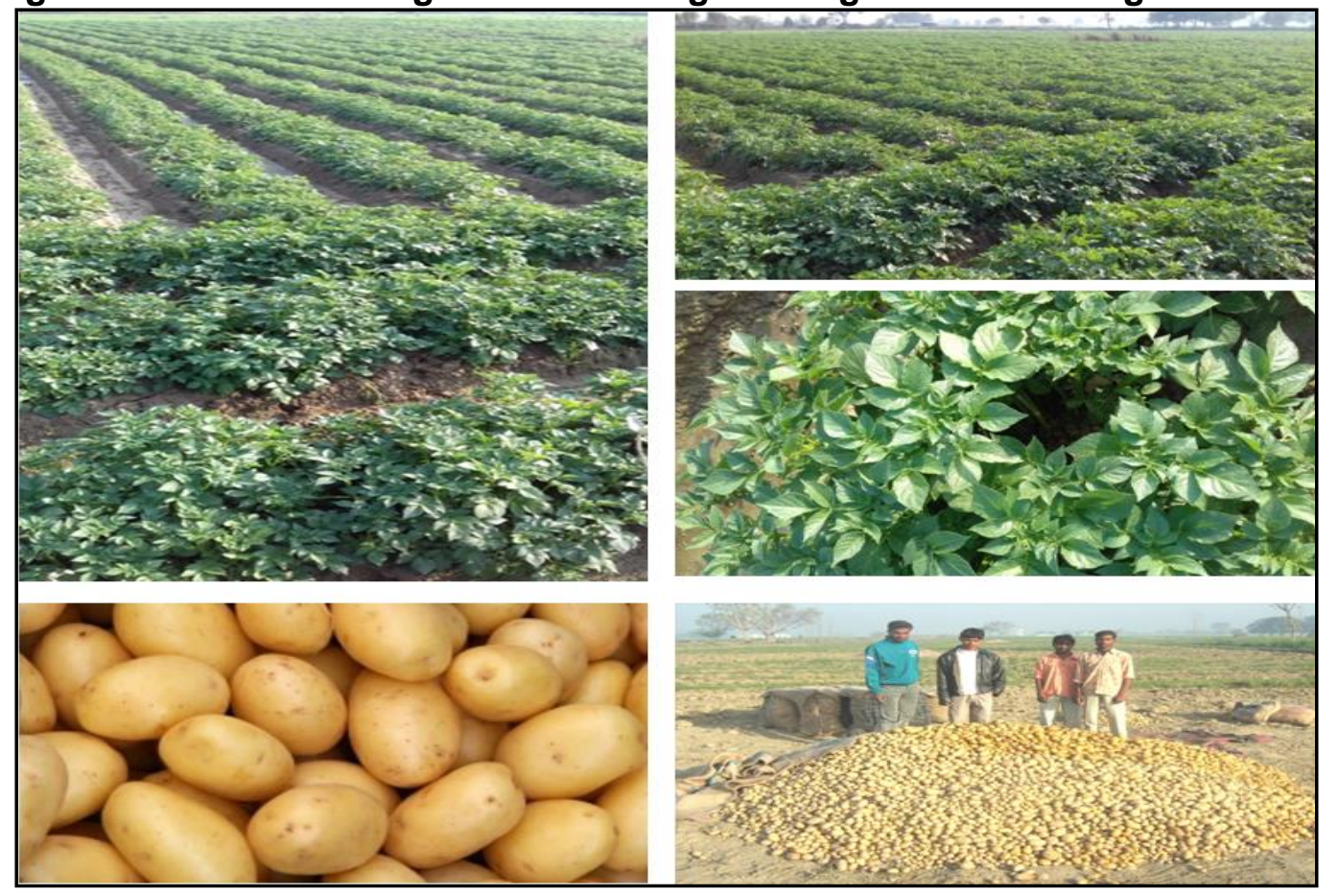

Source: Photographs composed by the researcher.

\section{Factors Constraining the Potato Cultivation and Production}

\begin{tabular}{|l|l|l|}
\hline Production Related Factors & Socio-Economic Factors & Policy \& Institutional Factors \\
\hline - Physical environment and & - Social support to farmers & - Neglect of the potato subsector \\
- production zones & - High production costs & - Inadequate capacity building \\
- Initiatives. \\
- Soil conservation & - Lack of credits & - Lack of support to farmers \\
- Water management & - Inefficienciaby of local markets & Organizations. \\
- Pest and disease mgmt. & - Limited access to higher & - Entrepreneurship development \\
- Harvesting & value markets. & - Research institutions \\
- Post-harvest management & - Lack of industrial support & - Skill Development programmes \\
\hline
\end{tabular}

Source: Based on the Report 'Sustainable Potato Production: Guidelines for Developing Countries, Food and Agricultural Organization of the United Nations, 2009

\section{Conclusion}

The area under potato cultivation in Aligarh district has observed a substantial increase from 5,425 hectares in 2001 to 24,987 hectares in 2016 as a result of which the production too has increased many times i.e. $14,29,433.25$ quintals in 2001 to $66,72,778.35$ quintals in 2016. This has shown sustainability in potato production in the district, which directly associated with the socio-economic growth of farmers. However, the potato farmers facing the constraints such as fluctuation in potato price, storage problems, potato seeds, irrigation, high price of diesel, not gets pesticides and fertilizers easily on subsidized rates. Many potato farmers especially small farmers store a small portion of their crops face so many problems in cold storage. If the proper 
policy for potato production and marketing implemented by the government potato can be used for several purposes like starch, alcohol, potato chips etc. (Singh and Rai, 2011). the government can also earn foreign exchange from the export of potato and potato products.

Socio-economic development of small and marginal farmers is also expected through proper vegetable cultivation and marketing in rural areas. Still, many constraints in increasing productivity and use of new technology are being faced by Indian farmers (Prakash, 2009). Adoption of rural marketing system may leads to some change because it provides a platform for employment, income, social change. Rural markets must link with bigger markets, which is only possible when proper transportation network is provided. Improved infrastructure and institutional arrangement such as private storage facilities, consciousness of food quality and standard among small income group even in village area also led to enhancement in vegetable cultivation. In addition, the processing of farm produce can also play an important role in conserving the farming systems and effective utilization of the produce (Asif, et al., 2016).

\section{References}

1. Adnan Shakeel, Ayesha Jamal and Md. Naiyer Zaidy (2012). A Regional Analysis of Food Security in Bundelkhand Region Uttar Pradesh, India, Journal of Geography and Regional Planning Vol. 5, No. 9, pp. 252-262.

2. Asif, K. (2014). Encroachment of Agricultural Land in Urban Fringe Areas of Aligarh City, India - Process and Parameters. Asian Geographer. Hong Kong Geographical Association, Hong Kong, Vol. 31, No. 2, pp. 129-148.

3. Asif, K., Khan, N. and Mushtaq, Y. (2016). Agro-Ecological Sustainability and Horticultural Fruit Gardening in the Sub-Himalayas of India: A Case Study on Livelihood Prospects and Problems Therein. Journal of Global Resources, Vol. 2, No. 1, pp. 53-61.

4. Census of India (2011). Provisional Population Totals, Office of the Registrar General and Census Commissioner, India, Ministry of Home Affairs.

5. Deshingkar, P., et al. (2003). Changing Food Systems in India: Resource Sharing and marketing Arrangements for vegetable production in Andhra Pradesh, Development Policy Review, Vol. 21, Issue 5-6, pp. 627-639.

6. District Statistical Booklet, Aligarh (2001-2014). Directorate of Statistics and Economics, Lucknow, Uttar Pradesh http://www.ipipotash.org/udocs/eifc no27-rf1.pdf.

7. Economic Census (2005). All India Report, Ministry of Statistics \& Programme, New Delhi.

8. Khan, N., Salman, M. S. and Rehman, A. (2009). Vegetable Revolution and Rural Sustainable Development: A Case Study, Revija Za Geografijo - Journal for Geography, No. 4, pp. 177-188.

9. Khan, N., Rehman, A., Salman, M.S. and Khan, M.M. (2012). Employment Generation through Vegetable Cultivation in North India, Asia-Pacific Journal of Social Science, Vol.4, No. 2., pp.135-52.

10. Khan, N. and Rehman, A. (2012). Vegetable Marketing in Rural Areas, Vista International Publishing House, New Delhi.

11. Khan, N., Salman, M.S. and Rehman, A. (2012). Dynamics and Diversification of Livelihood in Urban Fringe of Aligarh city, U.P., India, REVIJA ZA GEOGRAFIJO-Journal for Geography, University of Maribor, Slovenia, Vo1.7, No.1.

12. Lutaladio, N., Ortiz, O., Haverkort, A. and Caldiz, D. (2009). Sustainable Potato Production: Guidelines for Developing Countries. Food and Agricultural Organization of the United Nations, Rome, Italy, p.94.

13. N.H.B. (2014). National Horticulture Board. Ministry of Agriculture, Govt. of India.

14. Prakash, V. (2009). Constraints and suggestions regarding the technological gap in potato production technology in Uttar Pradesh. Journal of Community Mobilization and Sustainable Development, 4(11):16-19.

15. Singh, S.K. and Rai, P.P. (2011). The Potato Crop in Bihar: Status and Future Challenges, International Potash Institute, e-ifc, No. 27.

16. Varmudy, V. (2001). Marketing of Vegetables in India, Daya Publishing, New Delhi. 